\title{
Cytotoxicity and genotoxicity of stilbene derivatives in CHO-K1 and HepG2 cell lines
}

Cassia Suemi Mizuno ${ }^{1}$, Winnifred Ampomaah ${ }^{1}$, Fernanda Ribeiro Mendonça ${ }^{2}$, Gabriela Carvalho Andrade ${ }^{2}$, Ariel Maria Nazaré da Silva ${ }^{2}$, Mirian Oliveira Goulart ${ }^{1}$ and Raquel Alves dos Santos ${ }^{2}$

${ }^{1}$ Department of Pharmaceutical Sciences, University of New England - College of Pharmacy, Portland, ME, USA.

${ }^{2}$ Universidade de Franca, Franca, SP, Brazil.

\begin{abstract}
The cytotoxicity and genotoxicity of the stilbenes (E)-methyl-4-(3-5-dimethoxystyryl)benzoate (ester), (E)-4-(3-5dimethoxystyryl)aniline (amino), (Z)-1,3-dimethoxy-5-(4-methoxystyryl)benzene (cis-TMS) and (E)-1,3-dimethoxy5-(4-methoxystyryl)benzene (trans-TMS) were investigated in this work. Structural modifications of resveratrol, a naturally occurring stilbene, have been previously performed, including the replacement of hydroxyl by different functional groups. Such modifications resulted in significant improvement of target-specific effects on cell death and antiproliferative responses. The parameters were evaluated using XTT assay, clonogenic survival assay and the cytokinesis-block micronucleus assay in $\mathrm{CHO}-\mathrm{K} 1$ and HepG2 cell lines. The results showed that cis-TMS is approximately 250-fold more cytotoxic than the amino and ester, and 128-fold more cytotoxic than trans-TMS. When genotoxicity was evaluated, only the trans-TMS did not significantly increase the frequency of micronucleus (MN). While the cis-TMS induced a mean of 5.2 and $5.9 \mathrm{MN} / 100$ cells at $0.5 \mu \mathrm{M}$ in CHO-K1 and HepG2, respectively, the amino and ester induced 3.1 and 3.6 MN/100 cells at $10 \mu \mathrm{M}$ in CHO-K1, respectively, and 3.5 and 3.8 in HepG2. Trans-TMS is genotoxic only in HepG2 cells. Based on these results, the cis-TMS was the most cytotoxic and genotoxic compound in both cell lines.
\end{abstract}

Keywords: stilbene, cytotoxicity, genotoxicity, micronucleus assay.

Received: August 19, 2016; Accepted: January 29, 2017.

\section{Introduction}

Stilbenes comprise a class of plant-derived secondary metabolites that are produced in response to fungal infections (Flamini et al., 2016). Resveratrol is one of the most investigated stilbenes and has been found in many species of plants that are part of our diet such as grapes, peanuts, pomegranade and berries. Resveratrol became the focus of intense research after its presence in wine was associated with the French paradox in which a wine-drinking population with a high intake of saturated fat showed low incidence of cardiovascular diseases. The cardioprotective effects of this compound occur through different mechanisms including inhibition of platelet aggregation (Shen et al., 2007), vasorelaxation effects by upregulating NOS expression (Wallerath et al., 2002), and inhibition of LDL oxidation and subsequent atherosclerosis (Belguendouz et al., 1997). Resveratrol is also a scavenger of $\mathrm{H}_{2} \mathrm{O}_{2}$, a reactive oxygen species involved in oxidative stress (Ungvari et al., 2007).

Send correspondence to Raquel Alves dos Santos. Laboratory of Genetics and Molecular Biology, Universidade de Franca, Av. Dr. Armando Salles de Oliveira 201, 14404-600 Franca, SP, Brazil. E-mail: rasantosgen@yahoo.com.br
Other naturally occurring stilbenes with similar therapeutic potential include pterostilbene and piceatannol with anticancer (Seyed et al., 2016), anti-virus (Lee et al., 2016) antioxidant (Mikstacka et al., 2010), anti-inflammatory (Mikstacka et al., 2010), and lipid-lowering (Rimando et al., 2005) effects among others. Stilbenes reportedly inhibited the growth of several cancer cell lines such as colon, breast, prostate, pancreas, melanoma, lung and others. This effect is elicited through different mechanisms including cell cycle arrest and apoptosis induction via caspase activation (Aggarwal et al., 2004). Several animal studies support the evidence provided by the in vitro assays. Resveratrol prevented the formation of colon and intestinal tumors by $70 \%$ in Min mice (Schneider et al., 2001). 3,5,4'trimethoxystilbene (trans-TMS, Figure 1), a natural compound, significantly reduced tumor growth in Colo 205 xenograft model of colon cancer (Pan et al., 2008) and pterostilbene reduced the formation of azoxymethane-induced colonic aberrant crypt foci (ACF) (Suh et al., 2007). In a work by Paul et al. (2010), two stilbene derivatives (amino and trans-TMS, Figure 1) significantly decreased tumor volume and weight in HT-29 xenografts model of colon cancer. Based on the promising and pleiotropic effects of the 
<smiles>COc1cc(/C=C/c2ccc(N)cc2)cc(OC)c1</smiles>

(E)-4-(3,5-Dimethoxystyryl)aniline Amino<smiles>COc1ccc(/C=C\c2cc(OC)cc(OC)c2)cc1</smiles>

(Z)-1,3-dimethoxy-5-(4-methoxystyryl)benzene Cis-TMS

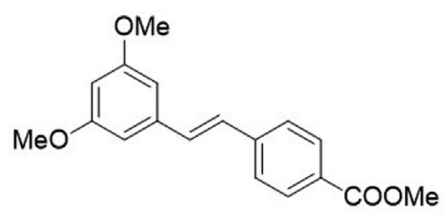

(E)-methyl-4-(3,5-dimethoxystyryl)benzoate Ester

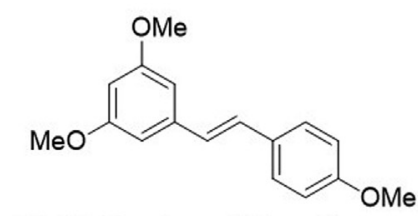

(E)-1,3-dimethoxy-5-(4-methoxystyryl)benzene Trans-TMS

Figure 1 - Chemical structure of stilbenes.

stilbenes, several clinical trials have investigated the effects of resveratrol and pterostilbene in patients with cardiovascular diseases, type 2 diabetes, chronic obstructive pulmonary disease and metabolic syndrome.

With the consideration of stilbenes as potential drug candidates, it is very important to determine the toxicity of these compounds. The genotoxicological analysis is of fundamental importance during toxicological evaluation of therapeutic drug candidates. Genotoxic compounds are capable of interacting with the DNA molecule, leading to genetic damage in essential regions for cycle-control and apoptosis, with the subsequent initiation of neoplastic processes (Santos and Takahashi 2008). Genotoxicity tests for screening substances (e.g. drug candidates, medicinal plant extract, chemical substance, etc) officially approved by the Organization for Economic Co-operation and Development (OECD) guidelines include in vitro micronucleus test to detect both clastogenic and aneugenic effects of potential drug candidates (Fenech, 2000).

The cytotoxicity and genotoxicity of the stilbenes (E)-methyl-4-(3-5-dimethoxystyryl)benzoate (ester), (E)-4-(3-5-dimethoxystyryl)aniline (amino), (Z)-1,3-dimethoxy-5-(4-methoxystyryl)benzene (cis-TMS) and (E)1,3-dimethoxy-5-(4-methoxystyryl)benzene (trans-TMS) (Figure 1) have not been reported in non-tumoral cell lines. Therefore, in the present study we investigated the cytotoxicity and genotoxicity of these stilbene derivatives using the CHO-K1 and HepG2 cell lines.

\section{Material and Methods}

\section{Chemicals and reagents}

Dimethyl sulfoxide (DMSO, CAS 67-68-5), cytochalasin B (CytB, CAS 14930-96-2), doxorubicin hydrochloride (DOX, CAS 25316-40-9) and reagents for cell culture and micronucleus tests were purchased from Sigma-Aldrich (St. Louis, USA). Cell Proliferation Kit (XTT) was purchased from Roche (Mannheim, Germany).
All solvents were anhydrous and all reactions were performed under an inert atmosphere, unless aqueous. All round-bottom flasks were kept dried in an oven under 100 ${ }^{\circ} \mathrm{C}$. Flash chromatography used to purify the compounds was done using a Teledyne Isco CombiFlash and LC-MS were obtained from Waters Micromass Quattro LC. The purity of all stilbenes tested was above $95 \%$.

\section{General procedure for the synthesis of stilbene derivatives}

To a cold solution $\left(-78^{\circ} \mathrm{C}\right)$ of phosphonium salt $(1.0$ equivalent) in THF was added $n$-butyllithium (1.6 mol in hexanes, 1.0 equivalent) and the resulting solution was stirred under inert atmosphere for $2 \mathrm{~h}$. A solution of aldehyde (1.0 equivalent) in THF was added dropwise, and the mixture was stirred for $12 \mathrm{~h}$ at room temperature. The resulting suspension was poured into water and extracted with dichloromethane. The organic phase was combined and dried over $\mathrm{MgSO}_{4}$, and concentrated under reduced pressure. The crude product was purified through automated flash purification elution with hexanes/ethyl acetate.

(E)-Methyl 4-(3,5-dimethoxystyryl)benzoate (ester): Reaction of (3,5-dimethoxybenzyl) triphenylphosphonium $4(300 \mathrm{mg}, 0.608 \mathrm{mmol}$ ) and methyl 4-formylbenzoate (100 $\mathrm{mg}, 0.608 \mathrm{mmol}$ ) afforded the ester as a white solid: $32 \mathrm{mg}$ (17\%). ${ }^{1} \mathrm{H} \mathrm{NMR}\left(\mathrm{CDCl}_{3}, 300 \mathrm{MHz}\right): \delta 3.83(\mathrm{~s}, 6 \mathrm{H}) ; 3.92(\mathrm{~s}$, $3 \mathrm{H}) ; 6.42(\mathrm{~s}, 1 \mathrm{H}) ; 6.68(\mathrm{~s}, 2 \mathrm{H}) ; 7.04-7.16(\mathrm{~m}, 2 \mathrm{H}) ; 7.53(\mathrm{~d}$, $2 \mathrm{H}, J=8.4 \mathrm{~Hz}) ; 8.01(\mathrm{~d}, 2 \mathrm{H}, J=8.4 \mathrm{~Hz}) .{ }^{13} \mathrm{C} \mathrm{NMR}\left(\mathrm{CDCl}_{3}\right.$, $75 \mathrm{MHz}): \delta 52.1,55.4(2 \mathrm{C}), 100.6,104.9(2 \mathrm{C}), 126.4(2 \mathrm{C})$, 128.1, 129.0, 130.1 (2C), 131.3, 138.8, 141.7, 161.1 (2C), 166.9. LCMS m/z 299.28. $(\mathrm{M}+\mathrm{H})^{+}$

(E)-4-(3,5-Dimethoxystyryl) aniline (amino). Reaction of (3,5 dimethoxybenzyl) triphenylphosphonium (300 $\mathrm{mg}, 0.608 \mathrm{mmol})$ and 4-nitrobenzaldehyde $(92 \mathrm{mg}, 0.608$ $\mathrm{mmol}$ ) afforded 1,3-dimethoxy-5-(4-nitrostyryl)benzene. A solution of the latter $(100 \mathrm{mg}, 0.35 \mathrm{mmol})$ in acetone/water $(10: 5 \mathrm{~mL})$ was heated to $50{ }^{\circ} \mathrm{C}$ for $30 \mathrm{~min}$. Sodium dithionite $(1526 \mathrm{mg}, 8.76 \mathrm{mmol})$ was slowly added and the 
mixture was heated to reflux for $1 \mathrm{~h}$. After cooled to room temperature the mixture was poured into water and extracted with ethyl acetate. The organic phase was combined and dried over $\mathrm{MgSO}_{4}$, and solvent was removed under reduced pressure. The crude mixture was purified using automated flash chromatography eluting with hexanes giving the amine as a yellow powder: $29 \mathrm{mg}$ (25\% yield) ${ }^{1} \mathrm{H}$ NMR $\left(\mathrm{CDCl}_{3}, 300 \mathrm{MHz}\right): \delta 3.82(\mathrm{~s}, 6 \mathrm{H}) ; 6.36(\mathrm{~s}, 1 \mathrm{H}) ; 6.63-6.69$ $(\mathrm{m}, 4 \mathrm{H}) ; 6.85(\mathrm{~d}, 1 \mathrm{H}, J=16.2 \mathrm{~Hz}) ; 7.00(\mathrm{~d}, 1 \mathrm{H}, J=16.2$ $\mathrm{Hz}) ; 7.33$ (d, 2H, $J=8.4 \mathrm{~Hz}) . \delta{ }^{13} \mathrm{C} \mathrm{NMR}\left(\mathrm{CDCl}_{3}, 75 \mathrm{MHz}\right)$ : $\delta 55.4$ (2C), 99.4, 104.3 (2C), 115.2 (2C), 125.1, 127.8, $127.9,129.3,140.1,146.4,161.0$ (2C). LCMS m/z 256.23 $(\mathrm{M}+\mathrm{H})^{+}$

1,3-dimethoxy-5-(4-methoxystyryl)benzene- cis and trans-TMS. Reaction of (3,5-dimethoxybenzyl)triphenylphosphonium (300 mg, $0.608 \mathrm{mmol}$ ) and 4-methoxybenzaldehyde $(75 \mu \mathrm{L}, 0.608 \mathrm{mmol})$ afforded the cis and trans-TMS. Trans-TMS as a white solid: $15 \mathrm{mg}(9 \%) .{ }^{1} \mathrm{H}$ $\operatorname{NMR}\left(\mathrm{CDCl}_{3}, 300 \mathrm{MHz}\right): \delta 3.83(\mathrm{~s}, 9 \mathrm{H}) ; 6.37(\mathrm{t}, 1 \mathrm{H}, J=2.1$ $\mathrm{Hz}) ; 6.65$ (d, 2H, $J=1.8 \mathrm{~Hz}) ; 6.87-6.89$ (m, 2H); 6.92 (d, $1 \mathrm{H}, J=5.1 \mathrm{~Hz}) ; 7.04(\mathrm{~d}, 1 \mathrm{H}, J=16.2 \mathrm{~Hz}) ; 7.45$ (d, 2H, $J=$ $6.9 \mathrm{~Hz}) .{ }^{13} \mathrm{C} \mathrm{NMR}\left(\mathrm{CDCl}_{3}, 75 \mathrm{MHz}\right): \delta 55.2(3 \mathrm{C}), 99.7$, 104.2 (2C), 114.2 (2C), 126.5, 127.8 (2C), 129, 130, 139.6, 159.4, 161.0 (2C). LC-MS $m / z$ 270.19. (M+H). ${ }^{+}$Cis-TMS as a viscous liquid: $62 \mathrm{mg}(37 \%) .{ }^{1} \mathrm{H}$ NMR $\left(\mathrm{CDCl}_{3}, 75\right.$ $\mathrm{MHz}): \delta 3.68(\mathrm{~s}, 6 \mathrm{H}) ; 3.78(\mathrm{~s}, 3 \mathrm{H}) ; 6.34(\mathrm{t}, 1 \mathrm{H}, J=2.4 \mathrm{~Hz})$; $6.44-6.46(\mathrm{~m}, 3 \mathrm{H}) ; 6.55(\mathrm{~d}, 1 \mathrm{H}, J=12.3 \mathrm{~Hz}) ; 6.78(\mathrm{~d}, 2 \mathrm{H}, J$ $=8.7 \mathrm{~Hz}) ; 7.24(\mathrm{~d}, 2 \mathrm{H}, J=8.4 \mathrm{~Hz}) \cdot{ }^{13} \mathrm{C} \mathrm{NMR}\left(\mathrm{CDCl}_{3}, 75\right.$ $\mathrm{MHz}): \delta 55.3$ (3C), 99.7, 106.7 (2C), 113.6 (2C), 128.7, 129.6, 130.2, 130.3 (2C), 139.5, 158.8, 160.6 (2C). LC-MS $\mathrm{m} / \mathrm{z} 271.28(\mathrm{M}+\mathrm{H})^{+}$.

\section{Cell culture and treatment conditions}

CHO-K1 and HepG2 cells were obtained from the Cell Bank of Rio de Janeiro (BCRJ code 0069 and 0103, respectively) and cultured in complete medium containing DMEM+F10 nutrient mixture $(1: 1, \mathrm{v} / \mathrm{v})$, supplemented with fetal bovine serum $(10 \%, \mathrm{v} / \mathrm{v})$ and penicillin/streptomycin stabilized solution $(10 \mathrm{~mL} / \mathrm{L})$. Cell cultures were incubated at $37{ }^{\circ} \mathrm{C}$ with atmosphere saturated with $5 \%$ of $\mathrm{CO}_{2}$. All experiments were conducted between the $3^{\text {rd }}$ and the $8^{\text {th }}$ passages and three experimental repetitions were performed.

The ester, amino, cis-TMS and trans-TMS were dissolved in DMSO in a stock concentration of $0.1 \mathrm{M}$. The final concentration of DMSO during treatments did not exceed $0.1 \%(\mathrm{v} / \mathrm{v})$ in cell cultures. Doxorubicin (DOX) was dissolved in ultrapure sterile water in a stock solution of $900 \mu \mathrm{M}$. All reagents were dissolved prior to use and protected from light. For all experiments, cells were submitted to $24 \mathrm{~h}$ treatment with different concentrations of the tested substance and DOX was used as positive control in CHO$\mathrm{K} 1$ cells. Benzo(a)pyrene $[\mathrm{B}(\mathrm{a}) \mathrm{P}]$ at $25 \mu \mathrm{M}$ was used as positive control in HepG2 cells.

\section{Cell viability assay - XTT}

To determine cell viability, $10^{4}$ cells/well were seeded on a 96-well plate. After $24 \mathrm{~h}$ the cells were treated with ester, amino, cis-TMS and trans-TMS in a concentration ranging from $7.8 \mu \mathrm{M}$ to $1000 \mu \mathrm{M}$ and incubated for an additional $24 \mathrm{~h}$. The plates were washed twice in phosphate buffer saline (PBS 1X) and incubated for $4 \mathrm{~h}$ at $37^{\circ} \mathrm{C}$ with DMEM without phenol red and supplemented with the reagents of the Cell Proliferation Kit (XTT) as recommended by the manufacturer. Total absorbance was measured at 492 and $690 \mathrm{~nm}$ (reference) using a microplate reader (ASYS, Eugendorf, Salzburg, Austria). Results of total absorbance were considered directly proportional to the number of viable cells as a percentage of the negative control (100\% of cell viability).

\section{Clonogenic survival assay}

The clonogenic assay was performed according to Franken et al. (2006). Briefly, 200 cells/well were plated in 6 well plates containing $3 \mathrm{~mL}$ of complete medium. After 4 $\mathrm{h}$ of incubation at $37^{\circ} \mathrm{C}$, the cells were treated with different concentrations of the testing stilbenes for $24 \mathrm{~h}$, then each well was washed with PBS $1 \mathrm{X}$ and complete medium was added. The cells were allowed to grow for 7-14 days at $37^{\circ} \mathrm{C}$ and $5 \%$ of $\mathrm{CO}_{2}$, when colonies were visible. The colonies formed were fixed with methanol/acetic acid/water $(1: 1: 8 \mathrm{v} / \mathrm{v} / \mathrm{v})$ and stained with Giemsa $5 \%(\mathrm{v} / \mathrm{v})$ in Sorensen phosphate buffer ( $\mathrm{pH}$ 6.8). The colonies were counted, and the cell survival fraction was calculated as percent colonies relative to the untreated control.

\section{Micronucleus test}

For the micronucleus test, $10^{6}$ cells were seeded in 25 $\mathrm{mm}^{2}$ culture flasks containing complete medium. Cell cultures were allowed to grow for $24 \mathrm{~h}$, then treated with different concentrations of the stilbene derivatives. Simultaneously, cytochalasin B $(6 \mu \mathrm{g} / \mathrm{mL})$ was added to each cell culture to inhibit cytokinesis. After $24 \mathrm{~h}$ of incubation, cells were harvested with a hypotonic treatment $(\mathrm{KCl} 0.075 \mathrm{M})$ and fixed twice with methanol:acetic acid (3:1). Thereafter, the cell suspension was smeared on pre-cleaned microscope slides and air-dried. Staining was performed during 15 min with Giemsa at 5\% in Sorensen Buffer (v/v). Microscope slides were washed in tap water and allowed to dry at room temperature overnight. The frequency of micronucleus $(\mathrm{MN})$, frequency of binucleated cells with micronucleus (BCMN) and frequency of nucleoplasmic bridges (NB) were obtained by the analysis of 1000 binucleated cell/culture/treatment as previously described by Fenech (2000). A total of 500 cells/culture/treatment were analyzed to determine the Nuclear Division Index (NDI) by scoring cells with 1, 2, 3 or 4 nuclei and using the formula: $\mathrm{NDI}=\mathrm{M} 1+2(\mathrm{M} 2)+3(\mathrm{M} 3)+4(\mathrm{M} 4) / \mathrm{N}$, where, M1-M4 stand for the number of cells with 1-4 nuclei and $\mathrm{N}$ is the total number of viable cells analyzed. 


\section{Statistical analysis}

Statistical analysis of experimental data was performed using the software GraphPad Prism 5.0. The $\mathrm{IC}_{50}$ was calculated by linear regression analysis and the comparative analysis among experimental groups was done with ANOVA, followed by Tukey's post-hoc test when significant differences among treatments were found. The significance was set at $p<0.05$ and the results were reported as means and standard deviations (SD) of three independent experimental samples assayed in triplicates.

\section{Results}

The cytotoxicity of stilbene derivatives in $\mathrm{CHO}-\mathrm{K} 1$ and HepG2 cells

The cytotoxicity of the stilbenes was determined by the XTT assay. Cells were treated with different concentrations of the tested stilbenes for $24 \mathrm{~h}$ and the results are presented in Figure 2. Cell viability was significantly reduced $(\mathrm{p}<0.05)$ by the ester at $62.5 \mu \mathrm{M}(73.3$ and $68.6 \%$ in CHO-K1 and HepG2, respectively). Significant reduction in cell viability by the amino was observed at $15.6 \mu \mathrm{M}$ $(67.2 \%)$ and $62.5 \mu \mathrm{M}(68.2 \%)$ in CHO-K1 and HepG2, respectively, and at all concentrations of the cis-TMS and trans-TMS in both cell lines. At the lowest concentration $(7.8 \mu \mathrm{M})$ of the $c i s-$ and trans-TMS, the cell viability was $60.7 \%$ and $62.5 \%$, respectively in CHO-K1, and $49 \%$ and $59.1 \%$ in HepG2 $(\mathrm{p}<0.05)$. Tukey's test demonstrated that the ester and amino induced a concentration-dependent reduction in cell viability, differently from what was observed for the cis and trans-TMS in both cell lines.

Subsequently, the long-term cytotoxic effects of stilbene derivatives were evaluated by the clonogenic sur- vival assay. Based on the XTT results, all stilbenes were tested in concentrations ranging from $2.5 \mu \mathrm{M}$ to $80 \mu \mathrm{M}$. However, no stilbene could form countable colonies at 40 and $80 \mu \mathrm{M}$ (data not shown). According to the results exhibited in Figure 3, in CHO-K1, the ester significantly reduced $(\mathrm{p}<0.05)$ the frequency of survival fraction at $20 \mu \mathrm{M}$ $(37.8 \%)$ and the amino at 10 and $20 \mu \mathrm{M}(67.1$ and $59.6 \%$ respectively). Similarly, in HepG2, $20 \mu \mathrm{M}$ ester significantly reduced the survival fraction (46.1\%) while significant response to amino treatment was observed at $5 \mu \mathrm{M}(59.3 \%)$. The trans-TMS showed a significant concentration-dependent reduction in the frequency of survival fraction in both cell lines. Interestingly, the cis-TMS showed much higher cytotoxicity than the other tested stilbenes and killed $100 \%$ of the cells in all concentrations tested in CHO-K1 cells and at $2.5,5$ and $10 \mu \mathrm{M}$ in HepG2. Therefore, this compound was tested at lower concentrations than the other stilbenes (Figure 4). The survival fraction was significantly reduced by the cis-TMS to $45.8,36.8$ and $13.9 \%$ at $0.078,0.156$ and $0.3125 \mu \mathrm{M}$, respectively in CHO-K1 cells and $41.3,54.3$, 16.9 and $6.2 \%$ at $0.078,0.156,0.3125$ and $0.625 \mu \mathrm{M}$ in HepG2.

\section{Genotoxicity of stilbene derivatives detected by cytokinesis-blocking micronucleus assay (CBMN)}

For the genotoxicity analysis, CBMN assay was performed to detect micronucleus frequency $(\mathrm{MN})$ and nuclear bridges (NB) in both CHO-K1 and HepG2 cells. According to the results presented in Figure 5, the ester, amino and cis-TMS increased MN frequency in CHO-K1 cells. However, no significant $\mathrm{MN}$ frequency $(\mathrm{p}<0.05$, compared to $\mathrm{NC}$ ) occurred in cells treated with trans-TMS at all concentrations. The ester increased the mean of MN to 2.7,3 and
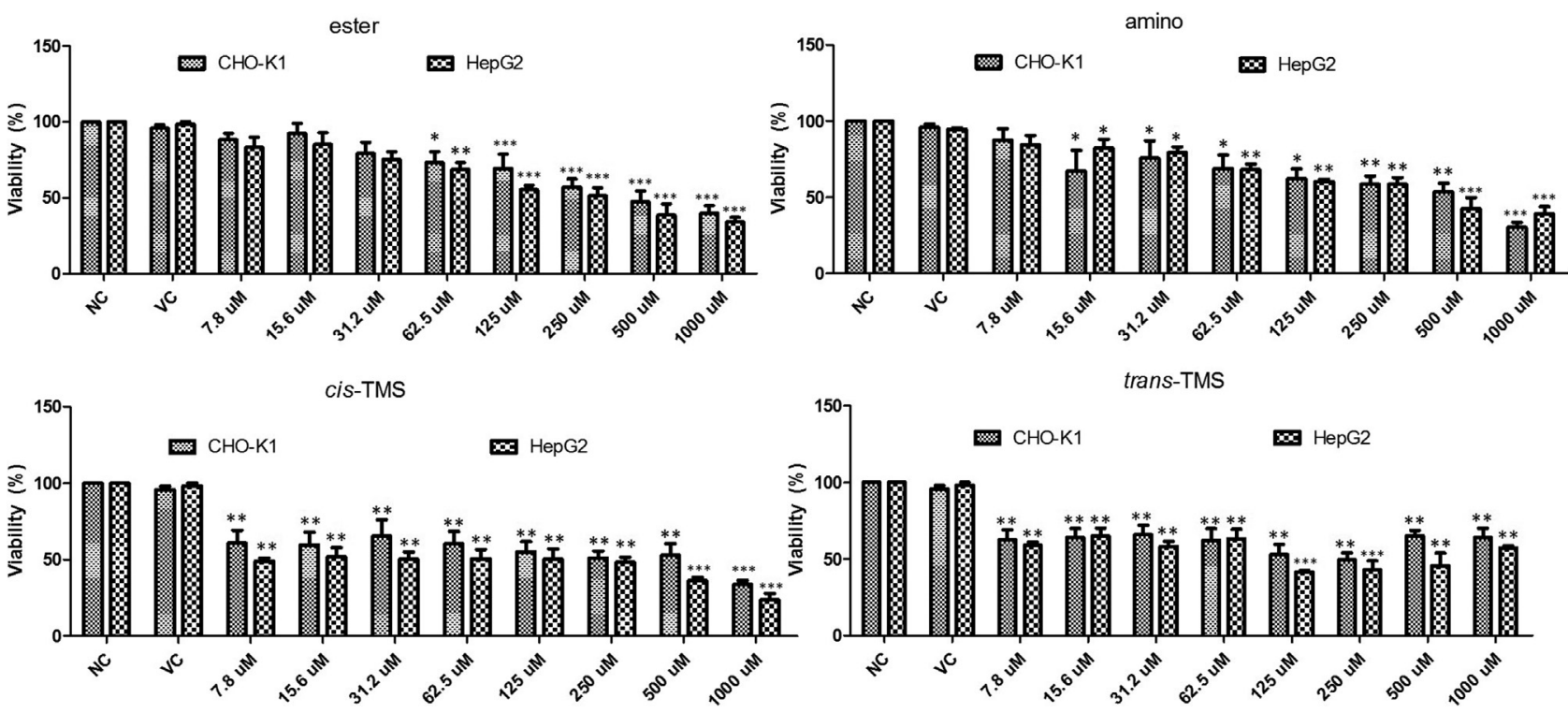

Figure 2 - Mean values of cell viability obtained by XTT assay in CHO-K1 and HepG2 cell lines after $24 \mathrm{~h}$ of treatment with different concentrations of ester, amino, cis-TMS and trans-TMS stilbenes. NC: negative control; VC: vehicle control (DMSO 0.1\%). ${ }^{*} p<0.05,{ }^{* *} \mathrm{p}<0.01$ and ${ }^{* * *} \mathrm{p}<0.001$ compared to negative control. 

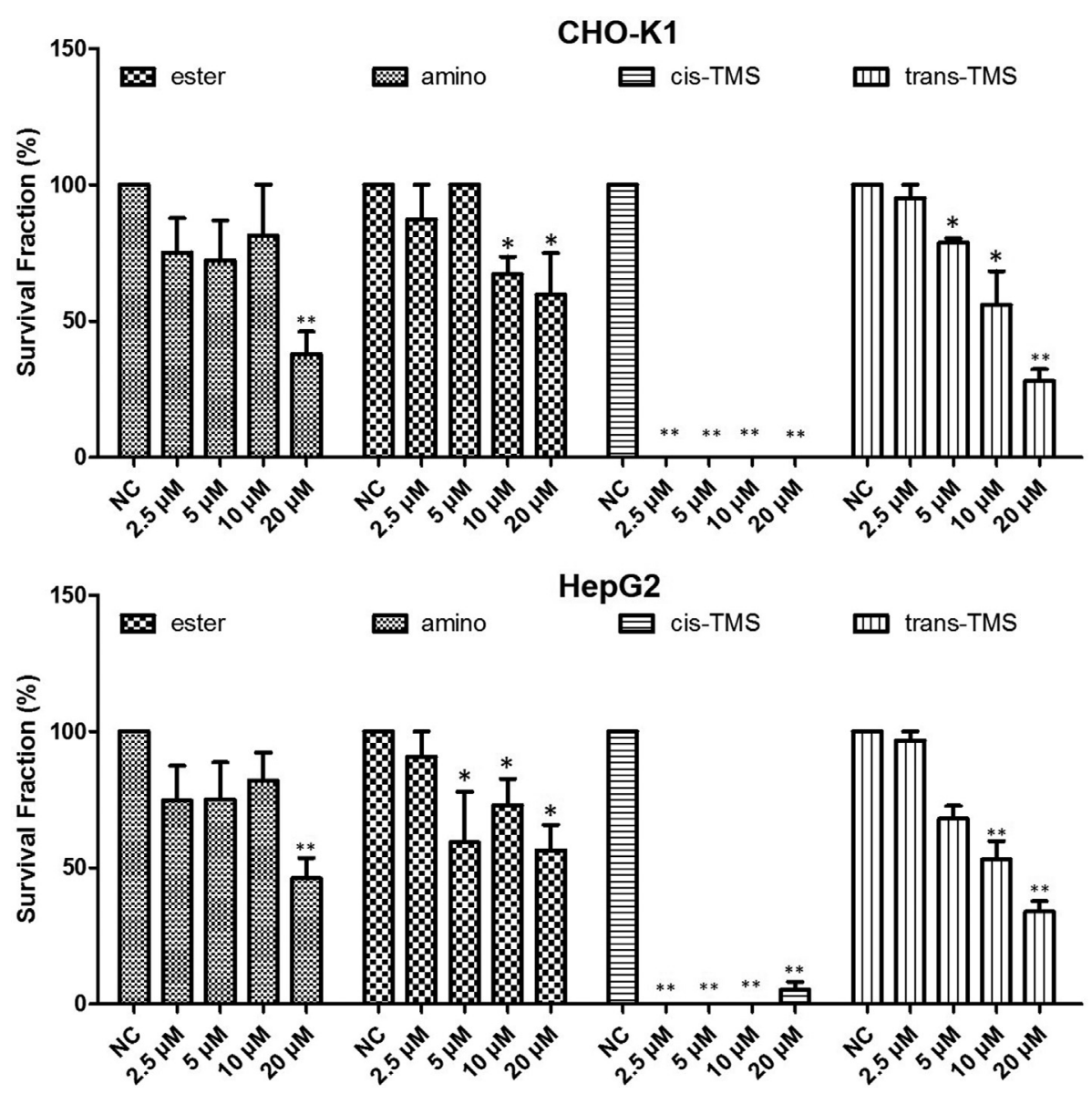

Figure 3 - Clonogenic assay showing the survival fraction of CHO-K1 and HepG2 cell lines after $24 \mathrm{~h}$ treatment with different concentrations of ester, amino, cis-TMS and trans-TMS stilbenes. Cells were treated for $24 \mathrm{~h}$ and allowed to grow during seven consecutive days. NC: negative control. ${ }^{*} \mathrm{p}<0.05$ and $* * \mathrm{p}<0.01$ compared to negative control.

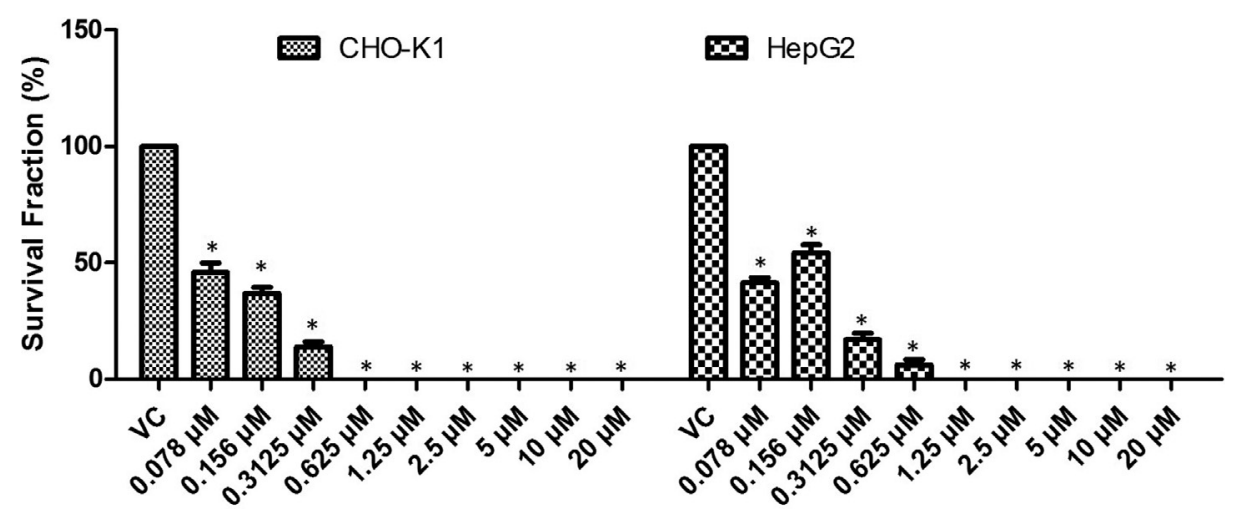

Figure 4 - Clonogenic assay showing the survival fraction of CHO-K1 and HepG2 cell lines after $24 \mathrm{~h}$ treatment with different concentrations of cis-TMS. Cells were treated for $24 \mathrm{~h}$ and allowed to grow during seven consecutive days. NC: negative control. ${ }^{*} \mathrm{p}<0.05$ compared to vehicle control.

3.1 at $2.5,5$ and $10 \mu \mathrm{M}$, respectively, in comparison to the $\mathrm{NC}$ (Figure 5). Similar effect was observed with the amino only at $10 \mu \mathrm{M}$, where $3.6 \mathrm{MN}$ were detected per 100 cell (p $<0.05$, Figure 5). All tested concentrations of cis-TMS increased the mean of MN in CHO-K1 cells. Even the lowest concentration tested $(0.125 \mu \mathrm{M})$ increased the mean to 2.8
MN/100 cells $(p<0.05)$. At the highest concentration $(0.5$ $\mu \mathrm{M})$, the frequency of MN was $5.2 / 100$ cells $(\mathrm{p}<0.001)$. Nuclear bridges were only observed in cells treated with the amino at $10 \mu \mathrm{M}$.

The analysis of genotoxicity in HepG2 revealed that all tested stilbenes increased the frequency of $\mathrm{MN}$ when compared to the negative control $(\mathrm{p}<0.05)$ (Figure 6). The 

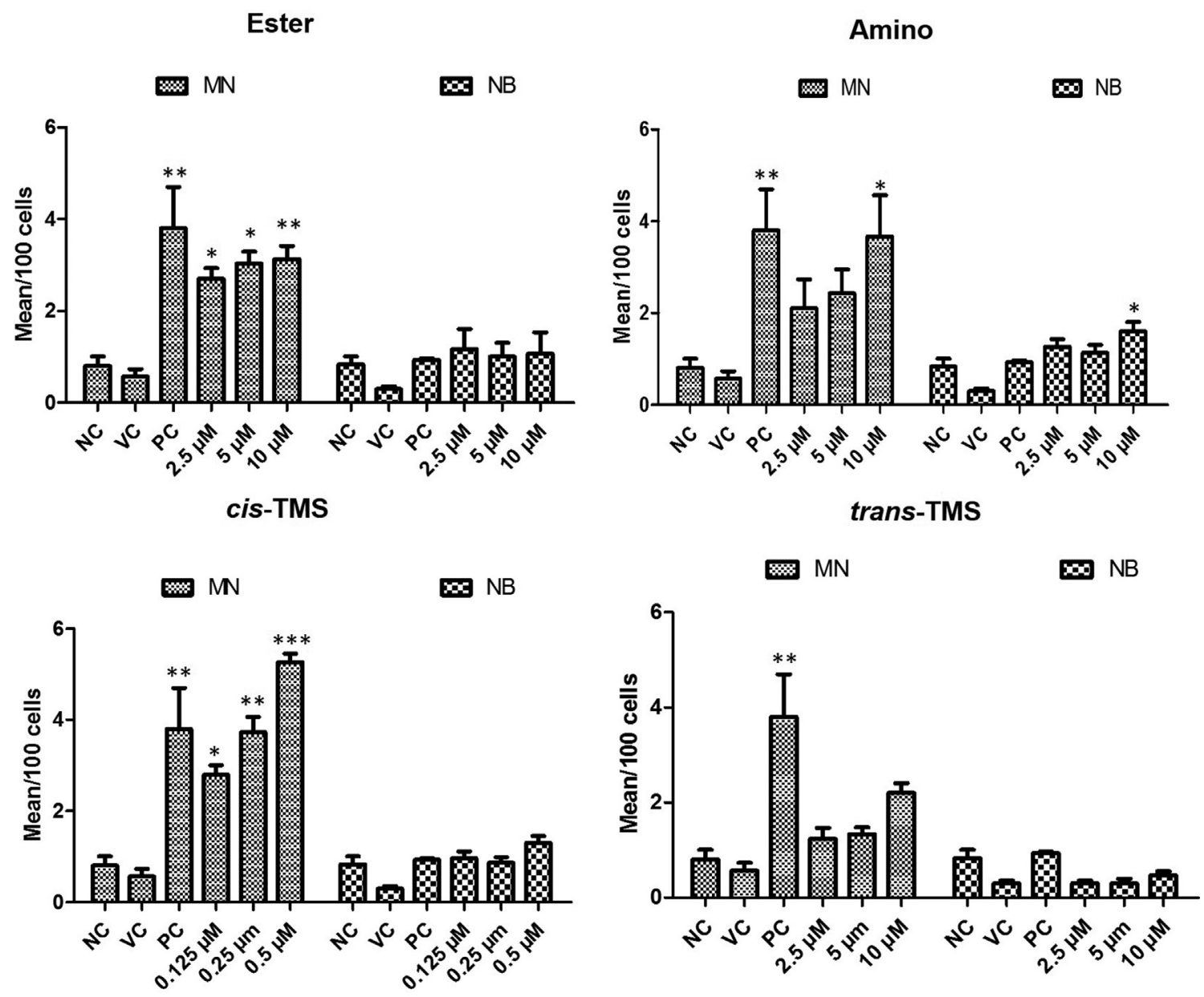

Figure 5 - MN assay showing the analysis of genotoxicity in CHO-K1 cells treated with different concentrations of ester, amino, cis-TMS and trans-TMS stilbenes. NC: negative control; VC: vehicle control (DMSO 0.1\%); PC: positive control (DOX $0.5 \mu \mathrm{M}$ in CHO-K1 and B(a)P $25 \mu \mathrm{M}$ in HepG2). *p $<$ $0.05, * * \mathrm{p}<0.01$ and $* * * \mathrm{p}<0.001$ compared to vehicle control.

lowest concentration of cis-TMS $(0.125 \mu \mathrm{M})$ induced a mean of $3.5 \mathrm{MN} / 100$ cells. At $0.5 \mu \mathrm{M}$ of $c i s$-TMS the frequency of MN observed was 6.1/100 cells. Treatments with ester increased the frequency of MN to $2.9(2.5 \mu \mathrm{M}), 3.3(5$ $\mu \mathrm{M})$ and $3.5(10 \mu \mathrm{M}) / 100$ cells, while amino induced 2.4, 2.9 and $3.8 \mathrm{MN} / 100$ cells at $2.5,5$ and $10 \mu \mathrm{M}$, respectively. Interestingly, the frequency of $\mathrm{MN}$ was significantly increased by trans-TMS treatments in all tested concentrations. No significant induction of nuclear bridges was observed in response to treatments with ester, amino, cis and trans-TMS in HepG2 cells.

No alteration in the nuclear division (NDI) was observed in response to any treatment when compared to the $\mathrm{NC}$ in both cell lines ( $\mathrm{p}>0.05$, Figure 7$)$.

\section{Discussion}

In the present study, the cytotoxicity and genotoxicity of the ester, amino, cis-TMS and trans-TMS stilbenes were investigated in CHO-K1 and HepG2 cell lines. CHO-K1 is recommended by the OECD for genotoxicity screening (OECD, 2014). However, HepG2 is more sensitive towards some genotoxins and enables detection of genotoxic carcinogens, which give negative results in other currently used bioassays, suggesting that in some cases, they might be more suitable than cell lines currently used for routine screening (Knasmüller et al., 2004). The cytotoxic (XTT) assay was performed to stablish the non-cytotoxic concentrations of the tested compounds to be used in the evaluation their genotoxic potential. The determination of the non-cytotoxic concentration is important because according to the OECD (2014) MN assay, cell proliferation must occur in both control and treated cultures to assess the extent of chemical-induced cytotoxicity or cytostasis in all of the cell cultures in which micronuclei are detected. Cytotoxicity of stilbene derivatives was determined using both the XTT and clonogenic survival assay, which evaluate the short and long term effects of a drug on cell viability and proliferation, respectively, and confirmed by the analysis of nuclear division index through the MN assay.

According to the XTT assay (Figure 2), the most cytotoxic compounds were the cis and trans-TMS, showing a significant reduction of cell viability at $7.8 \mu \mathrm{M}$ in both cell lines. The ester was the least cytotoxic compound with 

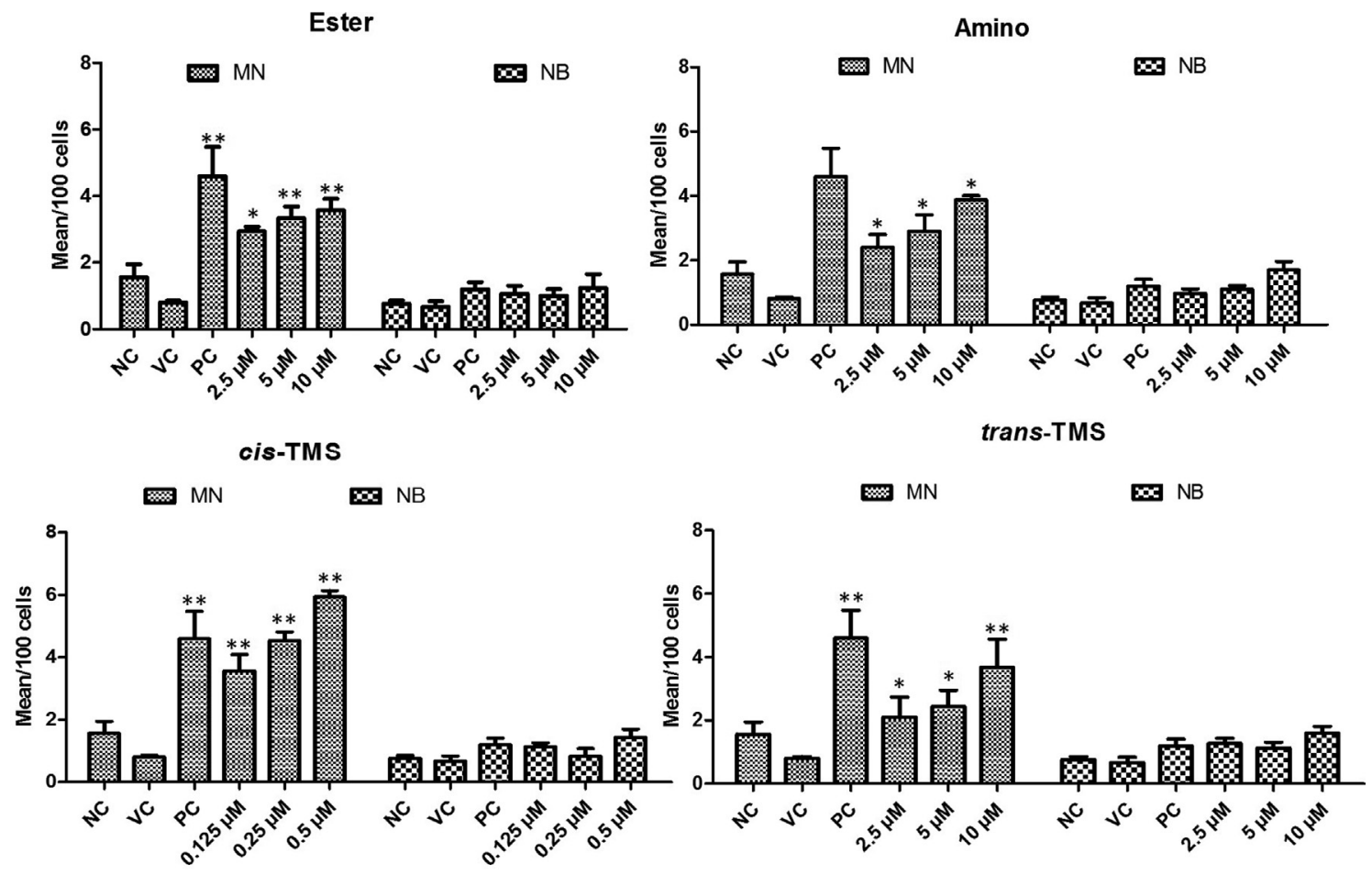

Figure 6 - MN assay showing the analysis of genotoxicity in HepG2 cells treated with different concentrations of ester, amino, cis-TMS and trans-TMS stilbenes. NC: negative control; VC: vehicle control (DMSO 0.1\%); PC: positive control (DOX $0.5 \mu \mathrm{M}$ ). ${ }^{*} \mathrm{p}<0.05,{ }^{* *} \mathrm{p}<0.01$ and ${ }^{* * *} \mathrm{p}<0.001 \mathrm{com}-$ pared to vehicle control.

a significant reduction of cell viability observed at $62.5 \mu \mathrm{M}$ in CHO-K1 and HepG2. The reduction of cell viability may be associated with necrosis or late stages of apoptosis, when the metabolic activity is severely reduced (Franken et al., 2006). Moreover, the surviving cells may be unable to proliferate because of reproductive integrity loss (Munshi et al., 2005). Therefore, the cell ability to form a clone and produce a viable colony needs to be evaluated to measure the long-term cytostatic/cytotoxic effects of the tested agent (Franken et al., 2006).

Once found that ester and amino were the least cytotoxic compounds as evidenced by XTT assay, and that in both cell lines cytotoxicity of ester and amino was detected from $62.5 \mu \mathrm{M}$, clonogenic survival was initially assayed in a concentration ranging from 2.5 to $80 \mu \mathrm{M}$, but at 40 and 80 $\mu \mathrm{M}$ no colony formation was detected. Moreover, in CHO-K1 no countable colony was detected after treatment with cis-TMS at all concentrations. The trans-TMS, ester and amino significantly reduced the colony formation starting at 5,10 and $20 \mu \mathrm{M}$, respectively (Figure 3 ) in both cell lines. The ester was the least cytotoxic in this assay. Suppression of colony formation by stilbenes may be essentially irreversible, raising the possibility that interactions between stilbenes and the molecular entities and events they target may be permanent rather than transient above a certain threshold concentration (Hsieh et al., 2011). Regarding the stereochemistry of the compounds, studies have shown that the cis-TMS is more cytotoxic than the trans isomer (Aldawsari and Velázquez-Martinez, 2015). According to Hsieh et al. (2011), experimental data about cellular signaling of PSA antigen in LNCaP cells, suggested that the stilbene core chemical structure instead of the side chain substitutions has a more critical role in controlling proliferative regulatory events.

Due to its high cytotoxicity, the cis-TMS was tested at lower concentrations in the clonogenic survival assay (Figure 4). Only at the $0.3125 \mu \mathrm{M}$ concentration and lower it was possible to detected survival fractions in CHO-K1, while in HepG2 colonies were detect at $0.625 \mu \mathrm{M}$. Based on the results from this assay, the cis-TMS is almost 250fold more cytotoxic than the amino and ester, and 128 -fold more cytotoxic than trans-TMS. In the CBMN assay the most genotoxic compound was the cis-TMS, which induced a mean of $5.2 \mathrm{MN} / 100$ cells at its highest concentration of $0.5 \mu \mathrm{M}$ in CHO-K1 and $6.1 \mathrm{MN} / 100$ cells in HepG2. This concentration was 5 times lower than the lowest concentration of the other stilbenes (Figure 5).

Both the cytotoxic and genotoxic effects of cis-TMS are in accordance with the results of in vitro studies reported in the literature. Schneider et al. (2003) demonstrated that the trans-TMS was 100-fold less effective in inhibiting the growth of Caco-2 cells than the cis isomer. Similar results were observed when cis and trans stilbenes were tested against five different cancer cell lines (Cushmann et al., 1991). In the work of Paul et al. (2010), the cis-TMS was the most cytotoxic in vitro but it was not active in vivo. The lack of activity was associated with its 
Ester

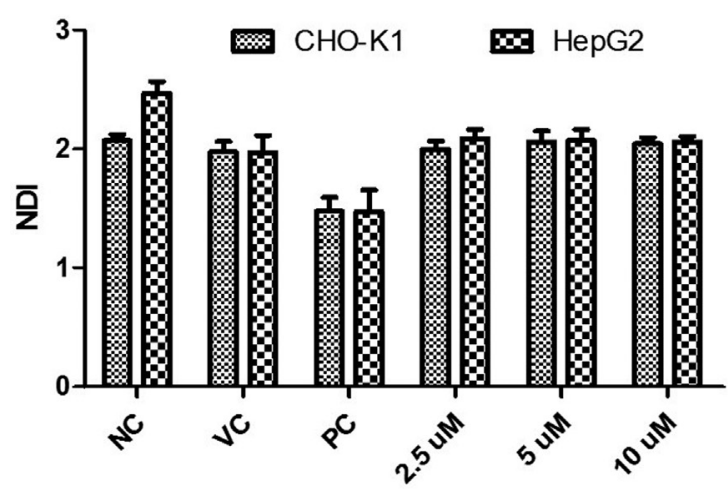

cis-TMS

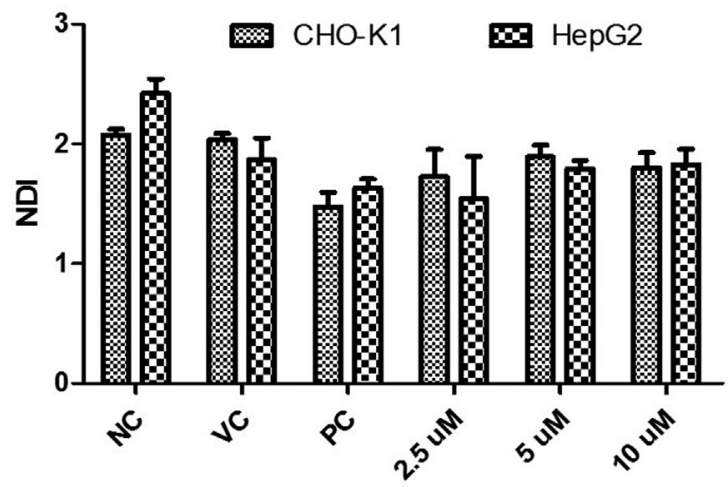

Amino

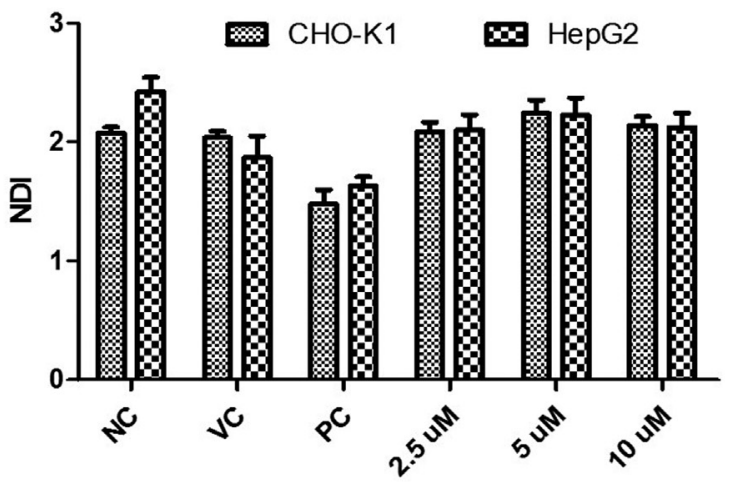

trans-TMS

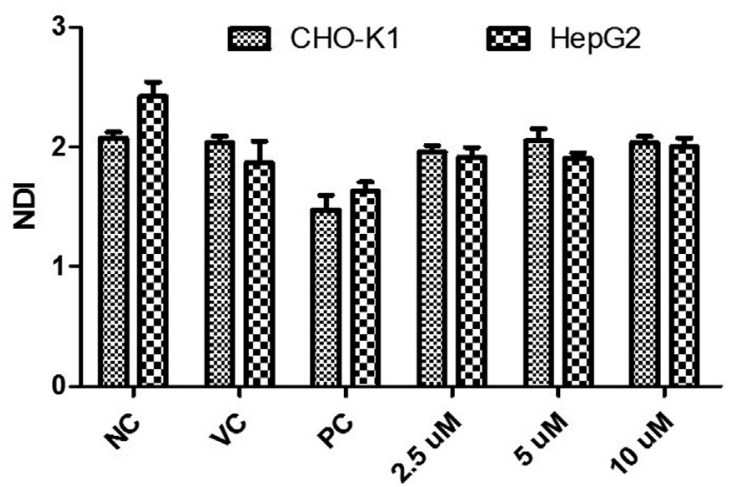

Figure 7 - Nuclear Division Index (NDI) obtained in CHO-K1 and HepG2 cell lines treated with different concentrations of ester, amino, cis-TMS and trans-TMS stilbenes. NC: negative control; VC: vehicle control (DMSO 0.1\%); PC: positive control (B(a)P $25 \mu \mathrm{M})$.

low bioavailability. The trans-TMS significantly reduced tumor volume in vivo, showing much higher serum levels than the cis-TMS. Our results clearly demonstrated that the cis- is more genotoxic than trans-TMS and the other stilbenes tested. However, interestingly, $\mathrm{CHO}-\mathrm{K} 1$ cells did not respond to trans-TMS treatment, while this stilbene was genotoxic in HepG2 cells, demonstrating the need for metabolization to exhibit genotoxicity. The cis-TMS also increased the frequency of $\mathrm{MN}$, which occurs when a whole chromosome or a fragment forms from a chromosome break and is not incorporated into one of the daughter nuclei during cell division. Genotoxic agents can damage DNA directly or indirectly by interacting with non-DNA targets leading to genotoxic effects, essentially through lipid peroxidation and protein adducts (Kirsch-Volders et al., 2003). As far as proteins are concerned, the literature reports inhibition of DNA repair enzymes, cell cycle control proteins, apoptosis-related gene products, nuclear lamins, defense proteins against oxidative damage, metabolization enzymes, and tubulins of the mitotic/meiotic spindle as mechanisms by which genotoxicants exert their effects (Kirsch-Volders et al., 2003).

Schneider et al. (2003) demonstrated that the growth inhibition of Caco-2 cells by cis-TMS was not related to a cytotoxic effect, but it was associated with the arrest of the cell cycle progression at the $\mathrm{G} 2 / \mathrm{M}$ transition phase. They postulated that the ability of a drug to block cells in $\mathrm{G} 2 / \mathrm{M}$ is consistent with a disruption of the mitotic spindles by interaction with tubulin. The authors also demonstrated that cis-TMS inhibited tubulin polymerization in a dose-dependent manner.

Despite the biological promising effects of stilbenes, little is known about their genotoxicological effects. The present study showed for the first time, that ester, amino, cis-and trans-TMS stilbenes exhibit genotoxic effects. The cis-TMS is significantly more cytotoxic and genotoxic than the other stilbenes, and the genotoxicity of trans-TMS requires metabolic activation. Further studies may elucidate the mechanisms involved in the genotoxicity of the stilbenes evaluated in the present work.

\section{Acknowledgments}

The authors acknowledge financial support by the Fundação de Amparo à Pesquisa do Estado de São Paulo (FAPESP grant 2014/12465-0 and fellowship 2015/16909-8). 


\section{References}

Aggarwal BB, Bhardwaj A, Aggarwal RS, Seeram NP, Shishodia $S$ and Takada Y (2004) Role of resveratrol in prevention and therapy of cancer: Preclinical and clinical studies. Anticancer Res 24:2783-2784.

Aldawsari F and Velázquez-Martínez CA (2015) 3,4',5-transTrimethoxystilbene; a natural analogue of resveratrol with enhanced anticancer potency. Invest New Drugs 33:775786.

Belguendouz L, Fremont L and Linard A (1997) Resveratrol inhibits metalion-dependent and independent peroxidation of porcine low-density lipoproteins. Biochem Pharmacol 53:1347-1355.

Cushmann M, Nagarathnam D, Gopal D, Chakraborti AK, Lin CM and Hamel E (1991) Synthesis and evaluation of stilbene and dihydrostilbene derivatives as potential anticancer agents that inhibit tubulin polymerization. J Med Chem 34:2579-2588.

Fenech M (2000) The in vitro micronucleus technique. Mutat Res 455:81-95

Flamini R, Zanzotto A, Rosso M, Lucchetta G, Vedova AD and Bavaresco L (2016) Stilbene oligomer phytoalexins in grape as a response to Aspergillus carbonarius infection. Physiol Mol Plant Pathol 93:112-118.

Franken NAP, Rodermond HM, Stap J, Haveman J and van Bree $\mathrm{C}$ (2006) Clonogenic assay of cells in vitro. Nat Protoc 1:2315-2319.

Hsieh TC, Huang YC and Wu JM (2011) Control of prostate cell growth, DNA damage and repair and gene expression by resveratrol analogues, in vitro. Carcinogenesis 32:93-101.

Kirsch-Volders M, Vanhauwaert A, Eichenlaub-Ritter U and Decordier I (2003) Indirect mechanisms of genotoxicity. Mutat Res 140-141:63-74.

Knasmüller S, Mersch-Sundermann V, Kevekordes S, Darroudi F, Huber WW, Hoelzl C, Bichler J and Majer BJ (2004) Use of human-derived liver cell lines for the detection of environmental and dietary genotoxicants; current state of knowledge. Toxicology 198:315-328.

Lee S, Yoon KD, Lee M, Cho Y, Choi G, Jang H, Kim B, Jung $\mathrm{DH}, \mathrm{Oh} \mathrm{JG}, \mathrm{Kim} \mathrm{GW}$, et al. (2016). Identification of a resveratrol tetramer as a potent inhibitor of hepatitis $\mathrm{C}$ virus helicase. Br J Pharmacol 173:191-211.

Mikstacka R, Rimando AM and Ignatowicz E (2010) Antioxidant effect of trans-resveratrol, pterostilbene, quercetin and their combinations in human erythrocytes in vitro. Plant Food Hum Nutr 65:57-63.

Munshi A, Hobbs M and Meyn RE (2005) Clonogenic cell survival assay. Method Mol Med 110:21-28.

OECD (2014) Test No. 487: In vitro mammalian cell micronucleus test. In: OECD Guidelines for Testing of Chemicals Section for Health Effects, 2014. OECD, Paris, pp 1-26.
Pan MH, Gao JH, Lai CS, Wang YJ, Chen WM, Lo CY, Wang M, Dushenkov S and Ho CT (2008) Antitumor activity of 3,5,4'-trimethoxystilbene in COLO 205 cells and xenografts in SCID mice. Mol Carcinog 47:184-196.

Paul S, Mizuno CS, Lee HJ, Zheng X, Chajkowisk S, Rimoldi JM, Conney A, Suh N and Rimando AM (2010). In vitro and in vivo studies on stilbene analogs as potential treatment agents for colon cancer. Eur J Med Chem 45:3702-3708.

Rimando AM, Nagmani R, Feller DR and Yokoyama W (2005) Pterostilbene, a new agonist for the peroxisome proliferator-activated receptor $\alpha$-isoform, lowers plasma lipoproteins and cholesterol in hypercholesterolemic hamsters. J Agric Food Chem 53:3403-3407.

Santos RA and Takahashi CS (2008) Anticlastogenic and antigenotoxic effects of selenomethionine on doxorubicin-induced damage in vitro in human lymphocytes. Mutat Res 46:671677.

Schneider Y, Chabert P, Stutzmann J, Coelho D, Fougerousse A, Gossé F, Launay JF, Brouillard R and Raul F (2003) Resveratrol analog (Z)-3,5,4'-trimethoxystilbene is a potent antimitotic drug inhibiting tubulin polymerization. Int $\mathrm{J}$ Cancer 107:189-96.

Schneider Y, Duranton B, Gossé F, Schleiffer R, Seiler N and Raul F (2001) Resveratrol inhibits intestinal tumorigenesis and modulates host-defense-related gene expression in an animal model of human familial adenomatous polyposis. Nutr Cancer 39:102-107.

Seyed MA, Jantan I, Bukhari SN and Vijayaraghavan K (2016) A comprehensive review on the chemotherapeutic potential of piceatannol for cancer treatment, with mechanistic insights. J Agric Food Chem 64:725-737.

Shen MY, Hsiao G, Liu CL, Fong TH, Lin KH, Chou DS and Sheu JR (2007) Inhibitory mechanisms of resveratrol in platelet activation: Pivotal roles of p38 MAPK and NO/cyclic GMP. Br J Haematol 139:475-485.

Suh N, Paul S, Hao X, Simi B, Xiao H, Rimando AM and Reddy BS (2007) Pterostilbene, an active constituent of blueberries, suppresses aberrant crypt foci formation in the azoxymethane induced colon carcinogenesis model in rats. Clin Cancer Res 13:350-355.

Ungvari Z, Orosz Z, Rivera A, Labin N, Xiangmin Z, Olson S, Podlutsky A and Csiszar A (2007) Resveratrol increases vascular oxidative stress resistance. Am J Physiol Heart Circ Physiol 292:H2417-H2424.

Wallerath T, Deckert G, Ternes T, Anderson H, Li H, Witte K and Forstermann U (2002) Resveratrol, a polyphenolic phytoalexin present in red wine, enhances expression and activity of endothelial nitric oxide synthase. Circulation 106:16521658 .

Associate Editor: Daisy Maria Fávero Salvadori

License information: This is an open-access article distributed under the terms of the Creative Commons Atribution License (type CC-BY), which permits unrestricted use, distribution and reproduction in any medium, provided the original article is properly cited. 